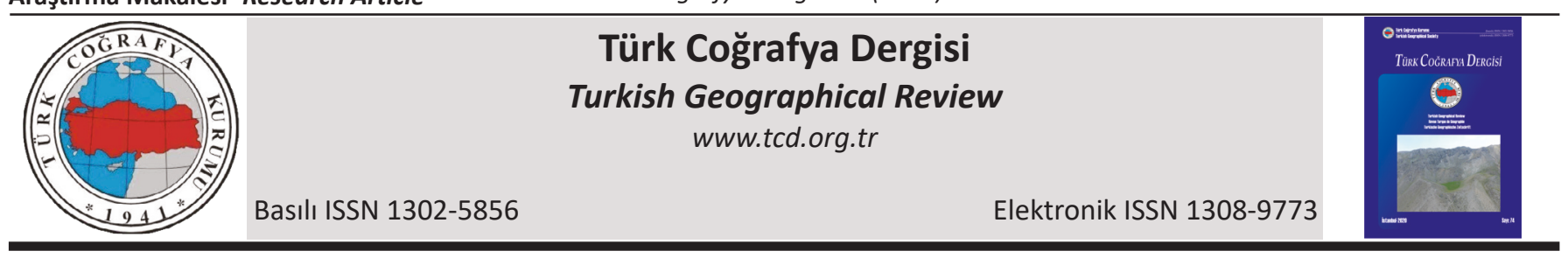

\title{
Küreselleşme bağlamında mekansal kent kimliği ve markalaşmanın kent turizmine etkisi ${ }^{1}$
}

\section{The influence on urban tourism of the spatial identify and branding in the context of globalization}

\author{
Okan Oğan*a (1) Üzeyir Yasak \\ a Uşak Üniversitesi,Fen Edebiyat Fakültesi, Coğrafya Bölümü, Uşak. \\ ${ }^{b}$ Uşak Üniversitesi,Fen Edebiyat Fakültesi, Coğrafya Bölümü, Uşak.
}

ORCID: O.O. 0000-0002-7340-1943; Ü.Y 0000-0002-2728-239X

\section{BILGI / INFO}

Geliş/Received: 12.03 .2020

Kabul/Accepted: 29.05 .2020

\section{Anahtar Kelimeler:}

Kent turizmi

Kent kimliği

Mekânsal kimlik

Turizm kentleri

Turistik mekanlar

Keywords:

City tourism

City identity

Spatial identity

Touristic cities

Touristic places

*Sorumlu yazar/Corresponding author:

(O. Oğan) ookanogan@gmail.com

\section{DOI: $10.17211 /$ tcd. 702812}

\section{Atif/Citation:}

Oğan, O. ve Yasak, Ü . (2020). Küreselleşme bağlamında mekansal kent kimliği ve markalaşmanın kent turizmine etkisi. Türk Coğrafya Dergisi (74), 97-105.

DOI: $10.17211 /$ tcd.702812

\section{ÖZ / ABSTRACT}

Doğal ve beşerî turizm kaynaklarını bünyesinde barındıran kentler, geçmişten günümüze turistlerin yoğun ilgi ve talebiyle karşılaşmaktadır. Modern turizmin gelişmeye başladığı ilk dönemden bu yana kıyı turizminin egemenliği söz konusudur. Son yıllarda kıyı turizmi ekseninde gelişen kentler, yoğun turizm talebine paralel olarak taşıma seviyesinin üzerinde turist akışı sebebiyle doyum noktasına ulaşmış durumdadır. Kıyı yerleşmelerinde bulunan doğal mekânların hızla tüketimi, tarihi ve kültürel mekanları ön plana çıkaran alternatif turizm kaynaklarının turistik açıdan değer kazanmasını sağlamıştir. Kentler, turizm ekonomisinden daha fazla pay almak amacıyla, kendine özgü tarihi ve kültürel mekanları markalaştırma yoluna gitmektedir. Bu bağlamda kentler arasındaki markalaşma ve kentsel kimlik oluşturma olgularının küreselleşme süreciyle olan ilişkisi birçok bilim dalı için ilgi çekici durumdadır. Turistlerin, sözü edilen fiziki ve beşeri turizm kaynaklarını mekânsal kimlik haline getiren kentlere olan ilgisi ve talebi gün geçtikçe daha da artmaktadır. Bu talebin odak noktası, markalaşmış ve kentsel kimlik haline gelmiş turistik değerleri görmek ve kültürel deneyim kazanmak olarak açıklanabilir. Bu araştırma, turizm kentlerinin kent kimliklerini oluşturmak ve bu kimliklerin markalaşmasıyla küreselleşme süreci arasındaki ilişki ve etkileri incelemek amacıyla hazırlanmıştır. Çalışmanın amacı, küreselleşme sürecinde kendine özgü fiziki ve beşeri turizm kaynaklarını kimlik haline getirip küresel turizm pazarına iyi bir şekilde tanıtan 'Marka kentler' ile sözü edilen kaynakları mekânsal kimlik haline getirme konusunda yetersiz kalmış, bu sebepten henüz "marka kent" olma yarışında geride kalmış turizm kentleri arasındaki farkları ortaya koymaktır. Araştırmanın amacına uygun olarak mekânsal markalaşmanın küreselleşme süreci üzerindeki etkisini ortaya koymak adına sözü edilen kentlerin betimsel analiz yöntemiyle karşılaştırması yapılmıştır. Araştırmanın hazırlık aşamasında marka kent kavramına uyan 16 Avrupa ülkesinden 28 şehir ziyaret edilmiştir. Bu kentler içinde Paris, Roma, Floransa ve Strazburg şehirleri örneklem olarak belirlenmiştir. Bu şehirlerin sahip olduğu doğal, tarihi ve kültürel birikimin markalaştırılması ve kimlik haline getirilmesi bağlamında küresel turizm pazarında daha çok öne çıktı̆ı sonucuna varılmıştır.

The cities including natural and humane tourism sources have been facing the intense interest and demand of tourists from past to present. Coastal tourism has had a dominance since the first developmental period of modern tourism. In the recent years, the cities developed by the sphere of coastal tourism have reached saturation point because of the over bearing level of tourist flow parallel to intense tourism demand. Fast consuming the natural environmental places in the coastal areas has led the alternative tourism sources that highlight historical and cultural places to gain touristic value. Cities follow the path of branding their own historical and cultural places to take more piece from tourism economy. In this context, the relationship between globalisation and branding of cities among other cities and forming identity facts has led an interest for most sciences. The interest and demand of tourists for the cities that form spatial identity of physical and humane tourism sources mentioned above have been getting stronger day by day. The focal point of this demand is to see touristic values and gain cultural experiences that transformed into brandind and city identity. This research is prepared to form the city identities of tourism cities and study the relatioship and effects between the branding of city identities and globalisation process. The aim of the study is to put the differences between the touristic cities that fail to turn their physical and humane tourism sources into spatial identity and fall behind in the competition and not become a "brand city" in the globalised tourism market. In accordance with the method of the research, the descriptive comparative study of these cities has been carried out in the name of the effects of spa-

\footnotetext{
${ }^{1}$ Bu çalışma Erasmus+ kapsamında 2019 Ocak-Haziran döneminde Macaristan Pecs Üniversitesine yapılan öğrenci hareketliliği sırasında arazi çalışmaları ve elde edilen istatistiki veriler üzerinden hazırlanmıştır.
} 
tial branding on the globalization process. In the preparation phase of the research, 28 cities of 16 European countries that are compitable with the concept of brand city was visited. Among these cities Paris, Rome, Florence and Strazburg are determined as the sample ones. It has been concluded that these cities have a bigger role in the globalized tourism market since they have branded and identified their natural, historical and cultural sources.

\section{Giriş}

Turizm, daimî yaşanılan yerden başka bir yere doğru eğlenme, dinlenme, eğitim, spor, sağlık vb. çeşitli amaçlarla yapılan, turistik tesislerin ürettiği mal ve hizmetlerin tüketildiği seyahatler ve geçici konaklama faaliyetleri olarak tanımlanabilir (Özgüç, 2015). Turizm kavramı, fiziki, ekonomik ve sosyo-kültürel etkileri sebebiyle antropoloji, şehir bölge planlama, ekonomi, arkeoloji, tarih vb. birçok farklı disiplinin önemli inceleme konuları arasında yer almaktadır. Coğrafyanın uygulamalı çaIışma alanları arasında yer alan Turizm Coğrafyası, turizm hareketlerinin mekânsal kalıpları, turizmin etkileri, turistik arz-talep ilişkileri, turistik çekicilik kaynakların coğrafi dağılımı, arazi kullanımında meydana gelen değişiklikleri, turizmin altyapı sistemleri ile ilişkileri vb. konuları coğrafyanın temel ilke ve yöntemleri kapsamında incelemektedir (Doğanay \& Zaman, 2016). Turizm Coğrafyası alt disiplin alanı, yörelerin turistik özelliklerini ve potansiyellerini belirleme, bunların turizm pazarındaki tanınırlığını sağlama, ekonomik gelir sağlanması, mekanların sürdürülebilir kullanımı ve korunmasının sağlanması vb. güncel konular üzerinde yoğunlaşmaktadır. (Deniz \& Yıldırım Kalem, 2018).

İnsanoğlu ilkçağlardan bugüne sürekli bir hareket halinde olmasına karşın turizm olarak nitelendirilebilecek hareketlerin geçmişi oldukça yenidir. Sanayi inkılabına kadar insanların mekân üzerinde yaptı̆ı hareketler turizm olarak değerlendirilecek niteliğe sahip değildi. Bu döneme kadar yalnızca toplumun zengin ve soylu kesimine ek olarak seyyahların katıldığı hareketler günümüz turizm olgusunun çekirdeği olarak yorumlanabilir. Sanayi inkılabı başta refah düzeyi ve boş zaman olmak üzere ulaşım sistemleri, iletişim olanakları vb. konularda sağladığı geliş̧meler sayesinde turizme katılan kişi sayısında önemli bir artş̧ı meydana gelmesine zemin hazırlamıştır.

İlkçağlardan sanayi inkılabına kadar soylu ve asillere mahsus olan turizm faaliyetleri, 19. yüzyılın başından itibaren daha çok kişinin katıldığı bir hareket haline gelmeye başlamıştır (Doğanay \& Zaman, 2016). 1945'e kadar süren Dünya Savaşlarının her alanda yaratth̆ı olumsuz etkiler sebebiyle kitlesel turizm hareketleri kesintiye uğramıştır. Bu tarihten itibaren turizm hareketleri yeniden hız kazanmaya başlamıştır (Theng, Qiong, \& Tatar, 2015). Modern turizm olarak nitelendirebileceğimiz kitlesel hareketler, 19. Yüzyılın başında Avrupa kıtasında başlayıp hızla dünyanın çeşitli coğrafi bölgelerine yayılmıştır (Emekli, 2002). Turizm sektöründe görülen bu gelişim 20.yüzyılın yarısına kadar yavaş bir hızda seyrederken Savaş dönemlerinin sona erip güvenlik ve huzur ortamı yeniden tesis edildikten sonra istikrarlı bir biçimde artş göstermiştir (Şekil 1). Güvenlik koşullarındaki iyileşmelere paralel olarak artan boş zaman algısı, maddi olanakların artı̧̧, ulaşım ve iletişim hizmetlerinde yaşanan geliş- meler de turizm olgusunun gelişimini hızlandırmıştır. Bu dönemle birlikte konaklama tesislerinin sayısı ve niteliğinin artması sayesinde turizm hareketleri çok daha sistematik bir hal kazanmıştır.

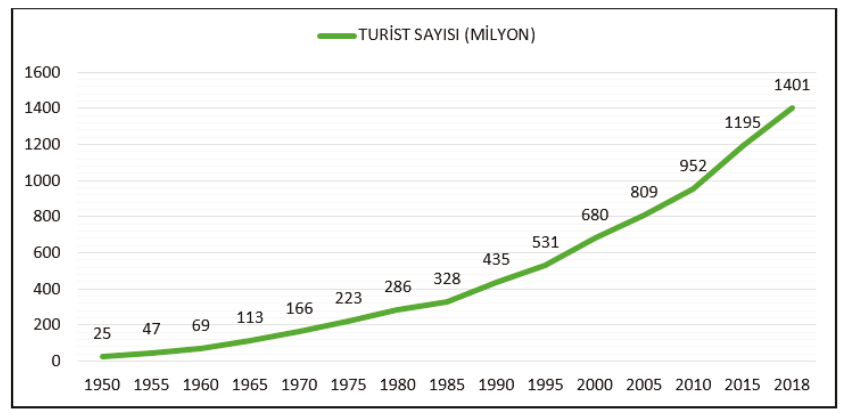

Şekil 1. Dünya turist akışının yıllara göre değişimi (Statista, 2020) Figure 1. The change of world tourist flow by years (Statista, 2020)

Turizm olgusu, fiziki, sosyal, kültürel ve ekonomik yapı üzerinde birtakım olumlu ve olumsuz etkilere sahiptir. Turizmin çevresel, ekonomik ve sosyo-kültürel yapı üzerine yaptı̆̆ etkiler nedeniyle fiziki ve beşerî birçok disiplinin başlıca inceleme alanı arasında yer almaktadır. Günümüzde farklı bilim dalları tarafindan yapılan araştırmalarda çoğunlukla turizmin ekonomik gelir getirici etkilerine odaklanılmış ve çoğu zaman fiziki çevreye verdiği hasar göz ardı edilmiştir. Bunun temel sebebi turizmin ekonomik faydalarına duyulan ihtiyacın yüksek olması olarak gösterilebilir (Bertan, 2009). Turizmin belirgin etkileri arasında ekonomik yapı üzerinde gelir getirici ve istihdam alanına yaptı̆ı olumlu katkılar öne çıkmaktadır (Sequeira \& Nunes, 2008). Turizm sayesinde ülkelerin hatırı sayılır miktarda döviz girdisi elde etmelerinin yanı sıra konaklama, restoran, ulaşım, tur ve gezi, eğlence, hediyelik eşya satışı vb. istihdam sahalarına önemli miktarda katkı sağlamaktadır (Yıldız, 2011). Fakat turizm olgusunun, fiziki çevre ve kıyı şeridi üzerine yaptı̆ı olumsuz etkiler, günümüzün en büyük çevresel problemleri arasında gösterilmektedir. Turizm, sahip olduğu fiziki ve ekonomik etkilerinin yanı sıra toplumları bir araya getirip kaynaştırması özelliği sayesinde kültürel yapı üzerinde de önemli değişimlere yol açar.

Modern turizmin gelişme göstermeye başladığı ilk yıllardan bugüne kıyı turizmi sektör içerisinde en fazla turist çeken turizm türü olarak bilinmektedir. Fakat son yıllarda kıyı yerleşmelerindeki turistik mekanların hızla tüketilmesi, bu destinasyonların taşıma kapasitelerinin aşılması ve turist eğilimlerinde görülen yapısal değişmeler sebebiyle alternatif turizm kaynakları önem kazanmaktadır. Bu sebepten ötürü ülkeler, turizm endüstrisinden daha fazla pay alabilmek amacıyla turistik ürünlerini çeşitlendirme arayışına girmektedir (Kervankıran \& Çuhadar, 2014). 
1970 'li yıllardan itibaren kıyı turizmine ek olarak alternatif turizm kaynakları önem kazanmaya başlamıştır (Smith \& Eadington, 1992). Bu durumdan dolayı da kentler, tarihi ve kültürel turizm kaynaklarını ön plana çıkararak turistik ürün haline getirme ve bunların tanınırlığını arttırma eğilimine girmiştir.

Küreselleşme son yıllarda git gide etkisini arttırmaktadır. Küreselleşme sürecinin literatüre kazandırdığı bir kavram olan "rekabetçilik", yalnızca ürünler arasında değil aynı zamanda mekanlar arasında da etkisini göstermektedir. Her kent, sözü edilen rekabet ortamında kendisine yer bulabilmek için uzmanlık alanlarını markalaştırarak küresel piyasada kendini ifade etmek amacı içerisindedir (Akturan \& Oğuztimur, 2016). Kentler, küreselleşme sürecinde avantaj elde etmek ve rakiplerinden farklılaşmak amacıyla fiziki ve beşerî değerlerini markalaştırma yoluna gitmektedir. Markalaşma, kentleri diğer kentlerden ayıran biricik özelliklerinin ön plana çıkarılma süreci olarak ifade edilebilir. Kentlerin markalaşma çabalarındaki temel amaç, yabancı toplumlar üzerinde olumlu bir algı oluşturmak ve potansiyel turizm pazarı için tanınırlığın arttırılmasıyla kenti cazibe merkezi haline getirmektir (Yalım, 2018).

Küreselleşme sürecinin getirdiği yoğun rekabet, kentleri markalaşmaya zorlamaktadır. Küresel pazarlar, dünyanın çeşitli coğrafyalarında yer alan kentleri marka kent olma sürecine dahil etmektedir (Kavaratzis, 2007). Dünya üzerinde çeşitli araştırma kuruluşları tarafindan hazırlanan birtakım kriterler kapsamında marka kent sıralamaları hazırlanmaktadır. Bu istatistikler genel olarak kentin fiziksel görüntüsü, konaklama şartları, yerli halkın tutum ve davranışları, turizm kaynakları ve çekim/cazibe destinasyonları, kentin uluslararası konumu vb. kriterler dikkate alınarak bir endeks hâlinde yayınlanmaktadır (Bitirim Okmeydan, 2018). Marka kent endeksi olarak bilinen bu istatistiklerin 2015 ve 2017 yıllarına ait verileri karşılaştrııldığında ilk 10 sırada yer alan marka kentlerin her iki yılda da büyük ölçüde benzerlik gösterdiği görülmektedir (Tablo 1). Bu benzerliğe istisnai bir durum olarak yalnızca 2015 yılında listede bulunan Washington'un yerine San Francisco'nun listeye dâhil olması gösterilebilir. Bunun haricinde listede bulunan marka kentlerin birbirleriyle olan sıralamalarında birtakım değişikliklerin meydana geldiği görülmektedir. Marka kent endeksinde ilk 10 sırada Avrupa kentleri ve Amerika Birleşik Devletleri sınırları içerisinde bulunan mega kentlerin çoğunlukta olduğu görülmektedir. Bunun haricinde Avusturalya'da yer alan Sydney ve Melbourne'un ilk 10 içerisinde yer alması da dikkat çekicidir (Martin, 2019).

Tablo 1. Marka kent endeksine göre ilk 10 sırada bulunan marka kentler Table 1. Top 10 Brand Cities According to Brand City Index

\begin{tabular}{|l|l|l|}
\hline $\mathbf{2 0 1 7}$ sıralaması & Marka Kent Adı & $\mathbf{2 0 1 5}$ siralamasi \\
\hline $\mathbf{1}$ & Paris & 1 \\
\hline $\mathbf{2}$ & Londra & 2 \\
\hline $\mathbf{3}$ & Sydney & 4 \\
\hline $\mathbf{4}$ & New York & 3 \\
\hline $\mathbf{5}$ & Los Angeles & 5 \\
\hline $\mathbf{6}$ & Roma & 6 \\
\hline $\mathbf{7}$ & Melbourne & 9 \\
\hline $\mathbf{8}$ & Amsterdam & 8 \\
\hline $\mathbf{9}$ & San Fransisco & Listede yok \\
\hline $\mathbf{1 0}$ & Berlin & $\mathbf{7}$ \\
\hline
\end{tabular}

Kaynak: (Martin, 2019)
Marka kent yarışında Avrupa ve Kuzey Amerika ülkelerinin yanı sıra Avusturalya sınırları içerisinde bulunan kentlerin ön planda olduğu görülmektedir (Tablo 1). Bu bağlamda Marka Kentlerin Avrupa, Kuzey Amerika ve Avusturalya Kıtalarında yoğunlaştığı göze çarpmaktadır. Marka kentlerin aksine Mekânsal kimliğini yeterince tanıtamamış ve turizm endüstrisinden hedeflediği payı elde edememiş kentlerin başında Afrika, Güney Amerika ve Uzakdoğu haricindeki Asya Kıtası'nda yer alan kentler gelmektedir. Özellikle Güney Amerika ve Asya Kıtalarının sahip olduğu sosyo-kültürel çeşitlilik göz önüne alındığında bu kentlerin markalaşma süreçlerinde mekânsal kimliklerini ön plana çıkarmaları büyük önem arz etmektedir.

Turizm destinasyonlarının tarihi, kültürel ve kentsel turizm kaynaklarını pazarlayarak turist çekmeye çalışmaları kent kimliği ve marka kent kavramlarının hızla önem kazanmasını sağlamıştr. Turistler, son zamanlarda tekdüze bir turizm anlayışından ziyade kentlerin kendine özgü turistik kaynaklarını deneyimlemek amacıyla hareket etmeleri, kentlerin birbirleriyle kıyasıya bir markalaşma ve kent kimliklerini tanıtma rekabeti içine girmelerine yol açmıştır.

\section{Kent Kimliği}

Kentler, nüfus miktarının yüksek olduğu, tarım dışı faaliyetler ve uzmanlaşmanın önem kazandığı yerleşim birimleri olarak bilinmektedir (Karadağ \& Mirioğlu, 2014). Kentsel sahalar, yalnızca fiziki bir mekân değil, aynı zamanda içinde yaşayan toplumlarla beraber dinamik sahalar olarak dikkat çeken yerleşim birimleridir. Bu bağlamda kentler, fiziki özellikleriyle beraber toplumsal ve ekonomik özellikleriyle de yaşayan mekânlar olarak bilinmektedir.

Kent kimliği, başta sosyal bilimler olmak üzere birçok bilim daIının inceleme alanı içerisinde yer alan bir kavramdır. Özellikle son yıllarda git gide popülerleşen kent kimliği kavramını her disiplin kendine özgü ilke ve yöntemleri vasıtasıyla incelemektedir. Sosyolog ve antropologlar kent kimliği konusuna kültürel bir perspektifle yaklaşırken şehir bölge planlamacılar, beşerî etkinin kent planı ve sistemleri üzerindeki yansımaları üzerinde yoğunlaşmaktadır. Tarihçiler, geçmiş çağlardan günümüze kalan tarihi mekân ve eserlerin kent kimliği haline getirilme süreci üzerine çalışmalar yapmaktadır. Coğrafyacılar ise kullandığı görsel materyaller ve kapsayıcı bakış açısıyla beraber kent kimliğinin insan-fiziki çevre etkileşimine ve mekânsal boyutlarına vurgu yapmaktadır. Kent kimliği, sözü edilen bu bilim dallarının haricinde mimarlık, ekonomi, arkeoloji, turizm vb. çok çeşitli disiplin tarafinda incelenen multidisipliner bir konudur.

Kentler de tıpkı insanlar gibi içerisinde barındırdıkları fiziki ve beşerî unsurlarla birlikte bir kimliğe sahiptir (Düzenli, Mumcu, \& Yılmaz, 2019). Kavramsal olarak kent kimliği, her kentte farklı özellikler gösteren birtakım fiziki, tarihi, sosyo-kültürel, ekonomik faktörlerin oluşturduğu geçmişten geleceğe devam eden bir sürecin yansımasıdır (Bingöl, 2017). Bir başka deyişle kent kimliği, uzum bir periyod içerisinde kentin coğrafi görünümü, kültürü, mimari yapısı ile şekillenen dinamik bir yapıdır. Tüm bu tanımlamalar dikkate alındığında en genel ifadeyle kent kimliği, bir kenti diğer kentlerden ayıran bileşenlerin tümü olarak tanımlanabilir (Kaypak, 2010). 
Kentlerin sahip olduğu tüm fiziki ve beşerî kaynaklar kent kimliğinin temel bileşenlerini oluşturur. Şehirlerin sahip olduğu klimatik özelliklere ek olarak jeomorfoloji, jeolojik yapı, bitki örtüsü vb. kentlerin mekânsal kimliğini oluşturan fiziki özelliklerini oluşturmaktadır. Örneğin kentler, sahip oldukları topoğrafik özelliklere göre "düz ve eğimli/engebeli şehirler" olarak sınıflandırılabilir. \% 4'ten az eğimli sahalar oldukça düz sayılırken \%10'un üzerinde eğime sahip araziler eğimli olarak kabul edilir. Bitki örtüsünün yapısal özelliklerine göre de kentler birbirlerinden ayrılmaktadır. Örneğin, İstanbul genellikle 'erguvan' rengi ile özdeşleşmişken Akdeniz bölgesinde yer alan kentler sahip oldukları 'palmiyeler' ile tanınır (Turgut, Yavuz Özalp, \& Erdoğan, 2012). Klimatik özelliklere göre ise kentler nemli/yağışlı ve kurak kentler olarak kategorize edilebilir. Ayrıca kentlerin güneşli gün sayısı, don yaşanan gece sayısı, bakı durumu, rüzgârlı gün sayısı vb. parametrelerine göre de bir sınıflandırma yapmak mümkündür. Tarihi geçmiş ile kent kimliği arasında sıkı sıkıya bir ilişki söz konusudur (Young \& Kaczmarek, 2008). Kentlerin demografik yapısı, yoğun olarak uğraşılan ekonomik sektör nüfusun kültürel yapısı (yaşam tarzını oluşturan gelenek-görenek, giyim, müzik, yemek alışkanlıkları vb. her türlü maddi ve maddi olmayan ögeler) kent kimliğini oluşturan beşerî kaynaklardır. Tüm bu fiziki ve beşerî kaynaklar, bir kenti diğerlerinden ayıran en önemli değerler olarak yorumlanabilir.

Kent planlama, mekânsal kimliğin inşasında oldukça önemli bir bileşen olarak göze çarpmaktadır. Dünyanın farklı coğrafyalarında yer alan kentler, sahip oldukları kent planlarıyla birbirlerinden büyük ölçüde ayrılmaktadır. Örneğin, Akdeniz havzasında bulunan kentlerin genellikle ticari bir düzene göre gelişmekte olduğu görülürken, İslam ülkelerinde yer alan kentlerin, merkezinde bulunan cami, medrese, han ve hamam gibi yapıların çevresinde geliştikleri görülmektedir. Ayrıca Roma-Bizans kentlerinde sıkça görülen agora-forum tipi meydanlar İslam coğrafyasında yerini külliyeleri içeren meydanlara bırakmıştır (Everest \& Yılmaz, 2019). Her kent, kendine özgü bir kültürel yapı içinde yaşayan mekânlar olarak bilinirler. Bu bakımdan kentlerin mekânsal kimliklerini oluşturan temel bileşenlerin başında tarihi-kültürel yapı gelmektedir. Örneğin; Venedik'in kanalları, Paris'te bulunan saraylar, katedraller, New York ve Hong Kong'daki gökdelenler kentlere kimliklerini veren tarihi yapılar olarak örnek gösterilebilir (Polat, Aktaş Polat, \& Halis, 2013).

Kentlerde bulunan simge yapılar, kent kimliği oluşturmada ve bu kimliğin tanınırlığının sağlanmasında önemli bir role sahiptir. Örneğin, Paris kenti denince akıllara ilk olarak Eiffel Kulesi gelmektedir. İtalya'nın başkenti Roma'da gladyatörlerin ve hatta zaman zaman insanlar ile hayvanların dövüştürüldüğü, idam törenlerinin gerçekleştirildiği Kolezyum Arenası kenti tanımlayan yegâne yapı olarak dikkat çekmektedir. Bu durum yalnızca Avrupa kıtasında yer alan kentlere özgü değildir. Amerika'nın New York şehri, Özgürlük Adasında bulunan Özgürlük Heykeli ile özdeşleşmiş durumdadır. Hindistan'ın Agra kentinde bulunan Taç Mahal'in şöhreti, Agra kentinden çok daha öteye yayılmıştır. Sözü edilen örneklerde de görüldüğü üzere simge yapılar olarak adlandırılan bu mekanlar, kent kimliğinin en önemli bileşenlerinden biri olarak dikkat çekmektedir.
Tablo 2. Bilbao Guggenheim Müzesi'ni ziyaret eden kişi sayısının yıllara göre değişimi

Table 2. Change in the number of people visiting the Bilbao Guggenheim Museum by years

\begin{tabular}{|l|l|}
\hline Yıllar & Ziyaretçi Sayısı \\
\hline 1997 (Ekim-Aralık arası) & 259,234 \\
\hline 1998 & $1,307,065$ \\
\hline 1999 & $1,109,495$ \\
\hline 2000 & 948,875 \\
\hline 2001 & 930,000 \\
\hline 2002 & 851,628 \\
\hline 2003 & 869,022 \\
\hline 2004 & 909,144 \\
\hline 2005 & 950,000 \\
\hline 2006 & $1,008,774$ \\
\hline
\end{tabular}

Kaynak: (Plaza, 2007)

Mekânsal kent kimliğinin önemli parçalarından biri olan simge yapıların markalaşmaya ve turizme etkisi önemini koruyan bir araştırma konusu olmasına karşın literatürde ilgili konuyu ele alan yeterli sayıda çalışmanın varlığından söz etmek güçtür. Simge Yapıların kent turizmine olan etkisini sistematize etmek amacıyla "Bilbao Etkisi" adı verilen bir kuram ortaya atılmıştır (Akbulut \& Ekşi Akbulut, 2008). Kurama göre mekânsal eşitsizlik, ekonomik istikrarsızlık ve işsizlik gibi problemlerle boğuşan Bilbao kentinde 1997 yılında inşa edilen Guggenheim Müzesi bir yapının mekânsal imaj üzerindeki etkisini ortaya koymaktadır. Nervion Nehri boyunca sıralanan yerleşim yerleriyle beraber nüfusu 1 milyona ulaşan Bilbao kenti, yaşadığı ekonomik krizlerin etkisiyle turistik açıdan yeterince gelişmiş bir kent konumunda değildi. Guggenheim Müzesi, hizmete açıldığı 19972006 yılları arası yılda ortalama 1 milyon, ayda ortalama 82.372 turiste ev sahipliği yapmıştır (Tablo 2). Guggenheim Müzesini ziyaret eden turistlerin yaklaşık \%80'inin (65.897 kişi) Bask kökenli olmaması ise simge yapının yabancı turist akışıyla ilişkisinin bir kanıt niteliğindedir. Bu bağlamda simge yapılarım kent markalaşması ve turizm sektörüyle ilişkisi "Bilbao Etkisi” kuramı adı altında literatüre girmiştir (Plaza, 2007).

\section{Amaç ve Yöntem}

Çalışmanın amacı, küreselleşme süreci kapsamında kentler arasındaki artan mekânsal kimlik oluşturma ve markalaşma rekabetinin kent turizmine etkisini ortaya koymaktır. Bu bağlamda mekânsal kent kimliğinin tanınırlığını sağlamış ve bunları markalaştırmayı başarmış kentlerle bu rekabette geri kalmış kentler turistik göstergeler üzerinden karşılaştırmıştır. Araştırmanın temel çatısını son yıllarda git gide popülerleşen kent kimliği, küreselleşme ve marka kent kavramları ekseninde görüşler oluşturmaktadır. Temel vurgu küreselleşme sürecinde doğal ve beşerî turizm kaynaklarını kentsel bir kimlik haline getirip bu ögelerini markalaştırmayı başarmış kentlerle bu süreci henüz 
tamamlayamamış kentlere göre sahip oldukları avantajlar tarthşılmaktadır. Bu kapsamda markalaşmış ve turistik değerlerini kimlik haline getirmeyi başarmış bazı küresel kentler ziyaret edilerek elde edilen bulgular ışığında kent kimliği ve markalaşma olgularının turistik gelişme açısından önemi üzerinde durulmuştur. Çalışma süresince 2019 yılı Ocak-Haziran döneminde 16 ülkeden 28 kent merkezi ziyaret edilmiştir (Tablo 3). Bu kentler içinde marka kent özelliğini daha iyi yansıtacağı düşünülen ve içinde belirgin simge yapıları barından 4 kent örneklem olarak seçilmiştir (Şekil 1). Bu kentler Paris, Roma, Floransa ve Strazburg'dur. Örneklemin belirlenmesinde kentlerin elde ettiği turist sayıları, bünyesinde barındırdığı simge yapılar, bu simge yapılara gelen ziyaretçi sayıları vb. kriterler dikkate alınmıştır. Ayrıca örneklem kentlerinin seçiminde Ocak-Haziran ayları arası gerçekleştirilen arazi çalışmaları kapsamında sözü edilen kentlerin ziyaret edilmesi etkili olmuştur. Bu kentlerde turizmle ilgili bakanlık, turizm büroları ve ofisleri, tur ve seyahat acenteleri vb. kurum ve kuruluşlarla görüşmeler yapılarak birincil veriler toplanmıştır. Kentlerin markalaştırdığı mekân ve simge yapılarla ilgili istatistiki veriler tablolaştrılarak genel turizm hareketlerindeki yeri tespit edilmeye çalışılmıştır. Ayrıca sözü edilen simge yapılar ziyaret edilip turistlerle yüz yüze görüşülerek çaIışma konusunu destekleyici bilgilere ulaşılmaya çalışılmıştır. Sözü edilen kentlerin mekânsal kimlik ve markalaşma durumlarını ortaya koymak adına betimsel analiz tekniği uygulanmıştr. Örneklem olarak seçilen kentleri ziyarete gelen turistlerle genel olarak kenti ziyaret etme nedenleri ve bu ziyaretlerinde simge yapıları görmenin etkisi üzerine sorular sorulmuştur. Ayrıca turistlerden ziyaret ettikleri kenti tanımlayan kimliksel ögeleri betimlemeleri istenmiştir.Yüz yüze görüşme gerçekleştirilen turistlerin büyük bir kısmının Paris'in kent kimliğini yorumlarken Eiffel Kulesi, Notre Dame Katedrali ve Şanzelize Caddesi, Roma'yı betimlerken Kolezyum Arenası ve Roma Forumunun üzerinde durduğu görülmüştür. Turistlerin Floransa'yı betimlerken çoğunlukla mimari yapısını vurguladıkları göze çarpmaktadır. Bu bağlamda örneklem olarak seçilen kentlerin ziyaret edilmesinde kent kimliğinin ve simge yapıların önemi anlaşımaktadır.

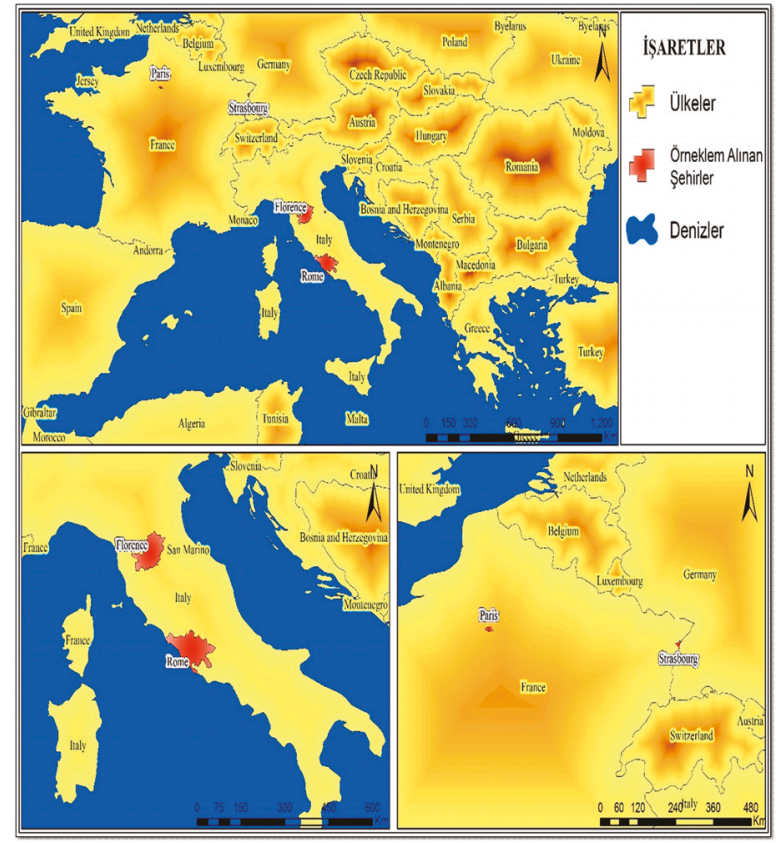

Şekil 1. Örneklem olarak belirlenen kentlerin lokasyon haritası Figure 1. Location map of cities determined samples
Tablo 3. Arazi Gezisi Düzenlenen Kentler ve Ülkeleri Table 3. Cities and Countries Organized Field Trip

\begin{tabular}{|l|l|}
\hline Kent Adı & Ülke Adı \\
\hline Pecs & Macaristan \\
\hline Budapeste & Macaristan \\
\hline Zagreb & Hirvatistan \\
\hline Prag & Çek Cumhuriyeti \\
\hline Viyana & Avusturya \\
\hline Vatikan & Vatikan \\
\hline Berlin & Almanya \\
\hline Munich & Almanya \\
\hline Amsterdam & Hollanda \\
\hline Brüksel & Belçika \\
\hline Brugge & Belçika \\
\hline Verona & İtalya \\
\hline Trieste & İtalya \\
\hline Milano & İtalya \\
\hline Padova & İtalya \\
\hline Roma & İtalya \\
\hline Napoli & İtalya \\
\hline Pisa & İtalya \\
\hline Floransa & İtalya \\
\hline Barcelona & İspanya \\
\hline Madrid & İspanya \\
\hline Paris & Fransa \\
\hline Strazburg & Fransa \\
\hline Porto & Portekiz \\
\hline Lizbon & Portekiz \\
\hline Sofya & Bulgaristan \\
\hline Atina & Yunanistan \\
\hline Luxembourg City & Luksemburg \\
\hline İstanbul & Türkiye \\
\hline & \\
\hline
\end{tabular}

\section{Araştırmanın Bulguları}

\subsection{Kent Kimliği ve Markalaşmasının Turizme Etkisinin Değerlendirilmesi}

Küreselleşme sürecinde kentlerin daha çok turiste ve turizm gelirine sahip olma arzusu, diğer rakiplerinden farklı ve özel olma eğilimine girmelerine yol açmıştır. Bunun için kentler, ilk olarak kendi doğal, tarihi ve kültürel zenginliklerini ön plana çıkararak bunların tanınırlığının arttırımasını sağlamaya çalışmaktadır. Turizm endüstrisinden daha fazla pay almak isteyen birçok kent, kendilerini diğer kentlerden ayıran fiziki ve beşerî ögeleri markalaştırarak kimlik haline getirme çabası içine girmektedir. Kentlerin mekânsal kimliklerinin tanınırlığını arttırma süreçlerini etkileyen birçok farklı araç ve yöntem mevcuttur. Bunun için öncelikle kentlerde yer alan yerel yönetimler, turizm büroları, seyahat acenteleri, rehber vb. kişi ve kurumlar tarafindan hazırlanan dergi ve broşürlerin yanı sıra kentlerde bulunan simge yapıların lokasyonlarının gösterildiği şehir haritaları turistik cazibe merkezlerinin tanıtımında kullanılan önemli materyallerdir. Ayrıca kentlerde bulunan yerel yönetimler tarafindan hazırlanan sloganların da markalaşma sürecini hızlandırdığı bilinmektedir (Pike, 2005). Bu görsel materyallerin yanı sıra kentlerde bulunan resmi ve özel müzeler vasıtasıly kentin zengin tarihi ve kültürel değerlerin tanınırlığının arttırılarak kent ile ilişkilendirilmesi amaçlanmaktadır. 
Bu araştırma süreci kapsamında, yaklaşık 5 aylık süre zarfinda 16 ülkeden çoğunluğu başkentler olmak üzere yaklaşık 28 kent ziyaret edilmiştir. Bu kentlerde bulunan turizm ofisleri, seyahat acenteleri ve tur şirketleriyle yüz yüze görüşmeler yapılmış, kent turizmi ve turist eğilimleri hakkında detaylı bilgiler edinilmiştir. Bu kurumlarla yapılan görüşmeler neticesinde kentleri ziyaret eden turistlerin, ziyaret amaçlarının başında kentte yer alan ayırt edici, biricik yapılar olan simge yapıları ziyaret etmek ve kent kimliğine ait bileşenleri deneyimlemek olduğu görülmektedir. Yani, geçmiş yıllara kıyasla turist eğilimlerini şekillendiren yegâne unsurların başında 'farklı olmak' gelmektedir. 'Farklılaşmayı' başarabilen ve ayırt edici ögelerini turizm pazarına yeterince tanıtabilen kentlerin daha fazla turist çektiği ve daha büyük gelir elde ettiği görülmektedir. Turizm ofislerinden ve bürolarından elde edinilen ikincil verilere göre, turistlerin kente gelir gelmez ilk ziyaret etmek istedikleri alanların kentte bulunan simge yapılar olduğu göze çarpmaktadır. Örneğin, Barcelona'yı ziyaret eden bir turist ilk olarak La Sagrada Familia Kilisesi önünde fotoğraf çekmek isterken, Prag kentine gelen bir başka turist, kentin tarihi bölgesi olan Historical Centre ile Prag Kalesi bölgesini birbirine bağlayan tarihi Karl Köprüsü üzerinde Vltava Nehri'nin sunduğu manzaranın tadını çıkarmayı tercih etmektedir.

Ziyaret edilen 28 kent içerisinde araştırmanın amacını yansıtması maksadıyla, kent kimliğini markalaştırmış ve bu marka kimliği dünya turizm pazarına tanıtmış Paris, Roma ve Floransa kentleri örneklem alanı olarak seçilmiştir. Bu kentlerin sahip olduğu fiziki, tarihi ve kültürel kimliklerinin yanı sıra simge yapılar olarak adı verilen ayırt edici yapılarının kent turizmindeki yeri ele alınmaktadır.

Tablo 4. Örneklem olarak seçilen kentlerden Paris, Roma, Floransa ve Strazburg'a gelen toplam turist sayısının yıllara göre değişimi (Milyon kişi) (20122018)

Table 4. The change of the total number of tourists coming from Paris, Rome, Florence and Strassbourg by years

\begin{tabular}{|l|l|l|l|l|l|l|l|}
\hline Kent Adı & $\mathbf{2 0 1 2}$ & $\mathbf{2 0 1 3}$ & $\mathbf{2 0 1 4}$ & $\mathbf{2 0 1 5}$ & $\mathbf{2 0 1 6}$ & $\mathbf{2 0 1 7}$ & $\mathbf{2 0 1 8}$ \\
\hline Paris & 17,9 & 16,8 & 16,6 & 16,8 & 16,7 & 17,7 & 17,5 \\
\hline Roma & 9,72 & 10,23 & 10,8 & 11,3 & 11,5 & 12,4 & 12,7 \\
\hline Floransa & - & 3,29 & 3,5 & 3,59 & 3,6 & 3,88 & 5,3 \\
\hline Strazburg & - & - & 0,7 & 0,9 & 1,0 & 1,0 & 1,2 \\
\hline
\end{tabular}

Kaynak: (Statista, 2020)

Tablo 5. Kent Kimliğini Oluşturan Önemli Simge Yapıları Ziyaret Eden Turistlerin Yıllara Göre Değişimi (Milyon kişi) (2012-2018)

Table 5. The Change of the Tourists Visiting the Important Iconic Building Constructing City Identity by Years

\begin{tabular}{|l|l|l|l|l|l|l|l|}
\hline Simge Yapı Ad1 & $\mathbf{2 0 1 2}$ & $\mathbf{2 0 1 3}$ & $\mathbf{2 0 1 4}$ & $\mathbf{2 0 1 5}$ & $\mathbf{2 0 1 6}$ & $\mathbf{2 0 1 7}$ & $\mathbf{2 0 1 8}$ \\
\hline Eifel Kulesi & 6,27 & 6,74 & 7,1 & 6,92 & 5,84 & 6,23 & 6,07 \\
\hline $\begin{array}{l}\text { Kolezyum ve Roma } \\
\text { Forumu }\end{array}$ & 5,20 & 5,62 & 6,18 & 6,55 & 6,40 & 7,03 & 7,65 \\
\hline $\begin{array}{l}\text { Floransa Boboli } \\
\text { Bahçeleri }\end{array}$ & - & 0,78 & 0,80 & 0,83 & 0,83 & 0,89 & 0,95 \\
\hline Zafer Tac1 & - & 1,77 & 1,75 & 1.76 & 1,34 & 1,58 & - \\
\hline Londra Kulesi & 2,44 & 2,89 & 3,07 & 2,78 & 2,74 & 2,84 & 2,85 \\
\hline $\begin{array}{l}\text { ABD Özgürlük } \\
\text { Heykeli }\end{array}$ & 3,03 & 1,88 & 4,2 & 4,28 & 4,5 & 4,44 & 4,34 \\
\hline ABD Lincoln Antt1 & 6,19 & 6,55 & 7,14 & 7,94 & 7,92 & 7,96 & 7,8 \\
\hline ABD Vitetnam Anit1 & 4,42 & 4,14 & 4,4 & 5,6 & 5,3 & 5,07 & 4,72 \\
\hline $\begin{array}{l}\text { Bilbaa } \\
\text { Guggenheim Müzesi }\end{array}$ & 1,01 & 0,93 & 1,01 & 1,10 & 1,17 & 1,32 & 1,26 \\
\hline Versay Saray1 & 7,2 & 7,5 & 7,7 & 7,3 & 6,7 & 7,7 & - \\
\hline
\end{tabular}

Kaynak: (Statista, 2020)
İtalya'nın başkenti Roma, en çok turist çeken kentlerin başında gelmektedir (Tablo 4) Roma'nın bu başarısının altında yerel kimliğini markalaştırması gelmektedir. Örneğin, Roma şehir merkezinde bulunan gladyatörlerin birbirleriyle ve hatta hayvanlarla dövüştürüldüğü, idam cezalarının gerçekleştirildiği tarihi Kolezyum Arenasının şöhreti ülke sınırlarını aşarak evrensel bir değer olma özelliği taşımaktadır. Ayrıca şehrin her bir noktasında rahatlıkla bulunabilen, İtalyan gastronomisinin farklı lezzetlerinin deneyimlenebileceği İtalyan restoranları Dünyanın dört bir yanında yaşayan turistlerin yoğun ilgisini çekmektedir. Roma kentinde bulunan tüm bu çekiciliklerin turistik ürün haline getirilerek tüketicilerin beğenisine sunulması tesadüf değildir. Roma şehri, sahip olduğu başta tarihi ve kültürel değerlerini "Romalı" kimliği adı altında markalaştırarak dünya turizmine tanıtmayı başarmıştır.

Paris metropolünü en iyi temsil eden yapıların başında hiç şüphesiz Eiffel Kulesi gelmektedir (Foto 1). Elde edilen istatistiki verilere göre yalnızca Avrupa kıtası ülkelerinden değil dünyanın dört bir noktasından Paris'i ziyaret eden turistlerin büyük bir bölümünün Eiffel Kulesini ziyaret ettikleri görülmektedir (Tablo 5). Paris'in çeşitli noktalarından kalkan ve Eiffel Kulesinde sonlanan "Eiffel Tour" isimli günlük turlara hatırı sayılır bir talep söz konusudur. Ayrıca Paris'in tüm turistik destinasyonlarında Eiffel Kulesi temalı hediyelik eşyalar, tişörtler, kartpostallar bulunmaktadır. Bu durum Paris'in Eiffel Kulesini ikonik bir simgesel yapı olarak markalaştırdığına ve bu marka kimliği sayesinde ciddi bir turizm gelirine sahip olduğunun çarpıcı bir örneği olarak dikkat çekmektedir. Eiffel Kulesi'nin dışında yeme-içme ve moda kültürünü de dünyaya tanıtmayı başaran Paris'in şık restoranlarında akşam yemeği yemek amacıyla veya Şanzelize Caddesi'nde alışveriş yapmak için şehri ziyaret edenlerin sayısı oldukça fazladır.

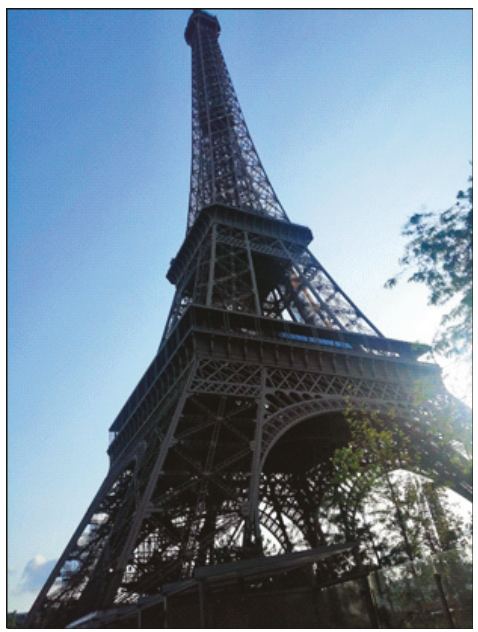

Foto 1. Paris Kent Kimliğinin en önemli simge yapısı olan Eifel Kulesi (Okan OĞAN, 2019)

Photo 1. The Most important icon Building of Urban Identify of Paris (Okan OĞAN, 2019)

Almanya ve Fransa arasında yer alan Strazburg kenti, Roma ve Paris'in aksine kültürel coğrafi görünümünü mekânsal kimlik halinde tanıtmayı başarmış bir kent olarak bilinmektedir. Strazburg, tıpkı bulunduğu coğrafi konumda olduğu gibi sahip olduğu kültürel yapıyla da iki ülkenin etkisi altında kalmış durumdadır. Kent, günümüzde Fransa sınırları içerisinde yer almasına karşın gerek sahip olduğu yerel mimari gerekse yaşayan yerli halkın kültürel yapısı açısından yoğun bir Almanya etkisi 
olduğu söylenebilir. Öyle ki, Strazburg'da yaşayan yerel halkın birçoğu kenti "En Fransız olmayan Fransa kenti" olarak tanımlamaktadır. Alman ve Fransız kültürleri arasında kalarak kendisine özgü kozmopolit bir kültür oluşturan Strazburg, kent içerisinde farklı kültürlerin sentezini deneyimlemek amacı taşıyan milyonlarca turiste ev sahipliği yapmaktadır. Birden çok kanal üzerine kurulan kent merkezi, Venedik'e benzeyen coğrafi görünümüyle ilgi çekmektedir (Foto 2). Roma ve Paris kadar olmasa da son zamanlarda farklı kültürleri bünyesinde barındırması ve sahip olduğu coğrafi görünümü tanıtmayı başaran Strazburg kenti, bu başarısının karşılığını son yıllarda giderek artan turist sayısı ve turizm gelirleriyle almaktadır.

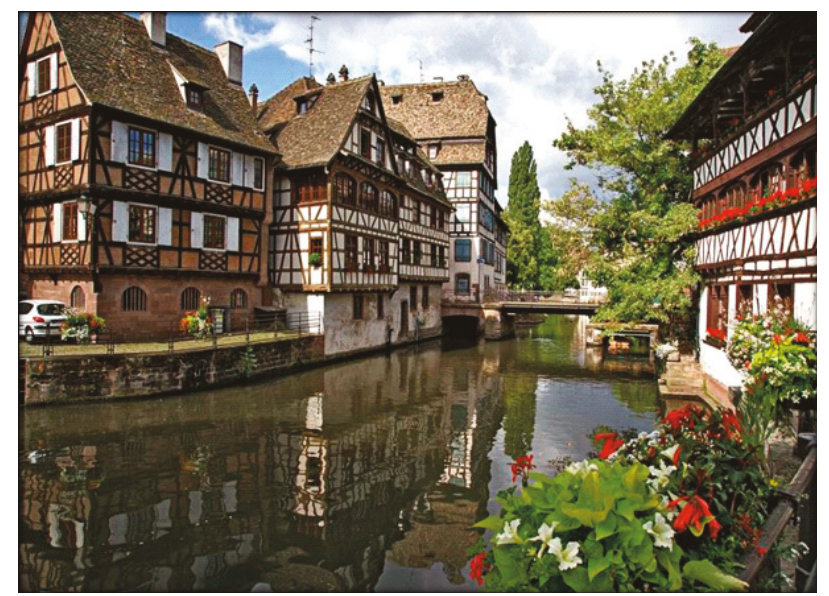

Foto 2. Strazburg'un markalaşmış 2 simge yapısı: Kanallar ve Mimari (Gezimanya, 2019)

Photo 2. The Two Branded Iconic Building of Strasbourg : Channels and Architecture (Gezimanya,2019)

Kent kimliğini oluşturan ögelerin başında mimari yapı gelmektedir. Her ne kadar kentlerin sahip olduğu geleneksel mimari tarzlar günümüzde popüler kültüre ait tekdüze mimari anlayışın etkisi altında olsa da hala yerel mimarisini korumayı başaran kentler mevcuttur. Bu kentlerin başında da İtalya'nın Toskana Bölgesinde yer alan Floransa kenti gelmektedir. Yüzyıllardır ayakta kalarak günümüze kadar ulaşan, birçoğu Rönesans döneminden kalma gotik tarza sahip mimari yapılar, Floransa'nın mimari özellikleriyle ön planda olan kentlerden biri olarak tanınmasını sağlayan en önemli özelliklerinden biridir (Foto 3 ve 4). Her yıl Floransa'ya gelen milyonlarca turistin kenti ziyaret etmesinde "Floransa Tarzı" olarak bilinen bu yapıları deneyimleme amacının ön planda olduğu söylenebilir.

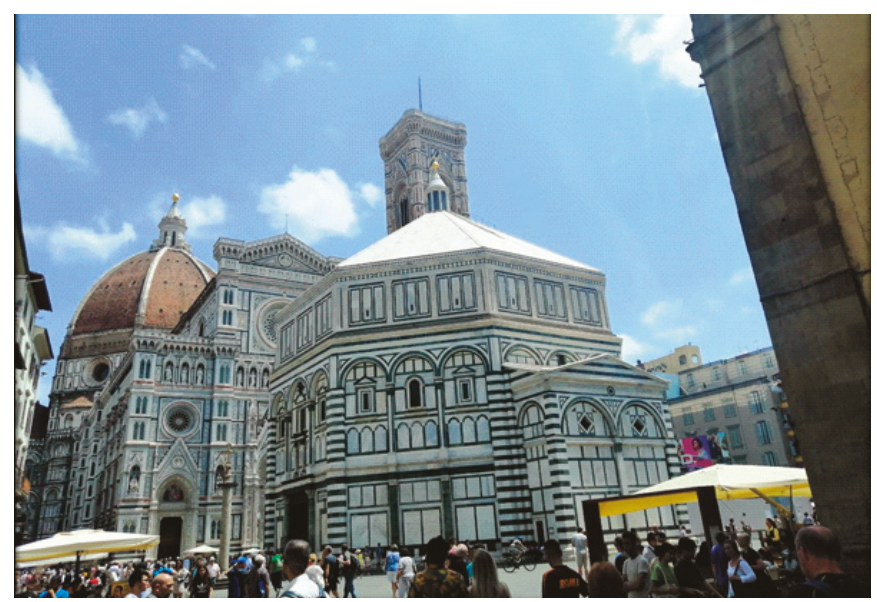

Foto 3. Floransa'nın önemli simge yapılarından : Aziz Giovanni Vaftizhanes (Okan OGAN, 2019)

Photo 3. One of the important Iconic Building of Florence: Baptistry (Okan OĞAN, 2019)
Öyle ki, Duomo Katedrali, Santa Croce Bazilikası gibi dini yapılar başta olmak üzere, Floransa'nın yerel mimarisine ait çok sayıda simge yapıya ait örneklerin yer aldığı Signoria Meydanı'nın gün içinde daima kalabalık olduğu görülebilir. Turistlerle yapılan görüşmeler neticesinde kentin ziyaret amaçlarında kent kimliğinin unsurlarını deneyimlemek ve marka değerleri yerinde görmek amacının ön planda olduğu görülmektedir. Özellikle Paris, Roma, Londra, Barcelona, Berlin vb. Avrupa kentlerini ziyaret eden turistlerin çok büyük bir bölümünün sözü edilen kentlerin sınırları içerisinde bulunan simge yapıları ziyaret etme güdüsüyle bu kentlere gelmektedir. Bu durum, simge yapıların kent turizmi ve kent kimliği oluşturmadaki önemini bir kez daha ortaya koymaktadır.

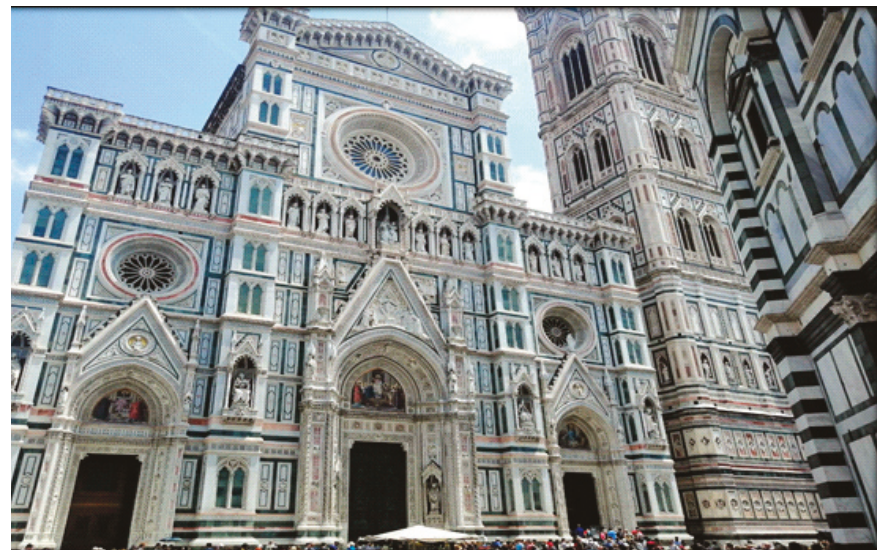

Foto 4. Floransa'nın önemli simge yapılarından: Santa Croce Bazilikası (Okan OĞAN,2019)

Photo 4. One of the important Iconic Building of Florence: Basilica of the Holy Cross (Okan OGAN, 2019)

\section{Tartişma ve Sonuç}

Turizm hareketlerine katılan kişi sayısında 1950'li yıllardan itibaren hızlı bir artış gözlemlenmiştir. Daha fazla kişinin turizme katılmasıyla birlikte elde edilen turizm gelirlerinde ciddi bir artış meydana gelmiştir. Birçok ülke, turizm endüstrisinden elde edilen gelir artsşına paralel olarak istihdam olanaklarının çeşitlenmesiyle birlikte ekonomik kalkınmalarını ciddi oranda hızlandırmıştır. Turizm endüstrisi çeşitli doğal ve beşerî turizm kaynaklarına sahip çok sayıda ülke ekonomisinde ekonomik gelir sağlayan sektörler arasında başı çekmektedir. Bu durum, ülkelerin turizmi geliştirici, tanınırlığını arttırıcı ve teşvik edici politikalar üretmesinin yolunu açmıştr.

Modern turizmin gelişmeye başladığı ilk günden bu yana kıyı turizmi egemen durumdadır. Fakat son yıllarda kıyı yerleşmelerinin taşıma kapasitelerinin aşılmasına paralel olarak turist eğilimlerinde görülen yapısal değişiklikler alternatif turizmin önem kazanmasını sağlamıştır. Bu gelişmeler ışığında turistik destinasyon tercihlerinin yavaş yavaş kıyı yerleşmelerinden tarihi mekânları barındıran yerleşmelere evirildiği görülmektedir. Ayrıca kentsel turizm kaynaklarıyla çekim merkezi durumuna gelen kentsel mekanlar da popülaritesini arttırmış durumdadır. Turist tercihlerinin tekdüze bir turizm anlayışından farklılıkların ön plana çıktığı bir anlayışa dönüşmeye başlamasıyla beraber kent kimliklerini markalaştırarak 'farklılaşmayı' başarabilen kentler turizm endüstrisinden daha fazla pay elde etmektedir. Bu durumdan dolayı birçok kent, daha çok turisti çekebilmek 
ve turizm gelirine sahip olmak amacıyla fiziki, tarihi, kültürel ve kentsel turizm kaynaklarını turistik ürün haline getirerek "markalaşma" rekabetine girmiş durumdadır.

Turizm, destinasyonlar üzerinde gelişme gösterdiği ilk dönemlerden bugüne ekonomik gelir elde etme, istihdam olanakları yaratma, ödemeler dengesine katkısı, döviz girdisi sağlama vb. birçok ekonomik etkiye sahiptir. Bunun yanında kentler arasındaki mekânsal eşitsizliğin azalmasına katkıda bulunması, turistik değeri olan doğal kaynakların korunup sürdürülebilir kullanımının sağlanması vb. birçok pozitif etkiye sahiptir. Çeşitli turistik mekanları bünyesinde barındıran kentlerin elde ettikleri turist sayısı ve turizm gelirinin artışına paralel olarak ekonomik kalkınma süreçlerinin hız kazandığı söylenebilir.

Kent kimliği, başta sosyal, kültürel ve dini olmak üzere kentlerin öz değerlerinden oluşan ve zaman içinde değişim gösterebilen dinamik bir yapıdır (Aktaş, 2016). Farklı doğal ve beşerî turizm kaynaklarına sahip olan kentler, turizmin gelişmesi ve tanınırlığının artmasına paralel olarak hızla gelişmektedir. Turizm olgusunun mekan üzerindeki etkisinin artmasıyla birlikte kentlerin demografik ve ekonomik gelişimi arasındaki ilişkinin fark edilmesi, kentlerin turizme verdiği önemin artmasını sağlamıştır.

Kentler arasında meydana gelen farklılaşma ve mekânsal kimliklerin markalaştırılması rekabetinde simge yapılar önemli bir role sahiptir. Paris ve Roma örneğinde de görüldüğü gibi uluslararası ölçekte tanınırlığa sahip simge yapılara olan ilgi gün geçtikçe artmaktadır. Sözü edilen kentlere turistik amaçlarla gelen ziyaretçilerin çok büyük bir kısmının simge yapılar olarak adlandırılan mekanları ziyaret etme amaçlarının ön planda olduğu görülmektedir. Bu bağlamda simge yapılar kentlerin sahip olduğu mekânsal kimliklerinin ayrılmaz bir parçası olduğu ve bu yapıların turizm endüstrisinden daha fazla pay sahibi olma süreçlerine katkıda bulunduğu göze çarpmaktadır.

Mekânsal kent kimliğini markalaşttrarak tanınırlığını sağlayan kentlerin turizm endüstrisinden elde ettiği gelir istikrarlı olarak artmaktadır. Buna karşın kentsel kimliği oluşturma sürecinde yeterli gelişme kaydedemeyen ve markalaşma yarışında geride kalan kentlerin turizm endüstrisinden yeterli ölçüde pay alamadığı görülmektedir. Marka Kentlerin çoğunlukla Avrupa ve Kuzey Amerika Kıtalarında yoğunluk kazandığı görülürken Güney Amerika (Brezilya, Arjantin, Kolombiya vb.), Afrika ve Asya Kıtalarında (Orta ve Güney Asya) bulunan kentlerin kent kimliklerini tanıtma rekabetinde geride kaldıkları görülmektedir. Bu durum, kentlerin markalaşma sürecinde avantajlı konuma gelmek adına geliştirdikleri kent kimliği kavramının turizm sektörü açısından önemini ortaya koymaktadır. Örneklem olarak belirlenen kentleri ziyaret eden turistlerle gerçekleştirilen görüşmeler neticesinde turistlerin ilgili kenti ziyaret etme sebepleri arasında simge yapılar ve markalaşan kent kimliğini deneyimleme isteklerinin ön planda olması bu durumu kanıtlar niteliktedir. Son yıllarda hız kazanan markalaşma rekabetinde geride kalan kentlerin, turizm endüstrisinde hedeflenen noktaya ulaşabilmeleri için mekânsal kimliklerini markalaştırarak tanınırlığının arttırılması büyük önem arz etmektedir.

\section{Kaynakça}

Akbulut, T. M., \& Ekşi Akbulut, D. (2008). Bir Kentin İmajını Değiştirmek: Simge Yapılar ve Turizm Sektörüne Etkisi. Turizm ve Mimarlık
2 Sempozyumu: 141-145.

Aktaş, A. (2016). Göç ve Modernleşme Bağlamında Siirt'te Değişen Kent Kimliği. Siirt Üniversitesi Ilahiyat Fakultesi Dergisi, 79-100.

Akturan, U., \& Oğuztimur, S. (2016). Kent Markalaşması Kavramının İçeriği ve Gelişimi: Farklı Disiplinler Farklı Yaklaşımlar. Şehir Plancıları Odası, 117-129.

Bertan, S. (2009). Turizmin Çevre Üzerinde Yarattğı Etkiler: Pamukkale Örneği. Anatolia: Turizm Araşttrmaları Dergisi, 204-214.

Bingöl, B. (2017). Kent Mobilyalarının Kentsel Mekanlarda Kent Kimliği ile İlişkilendirilmesi : Isparta Kaymakkapı Meydanı Örneği. Ileri Teknoloji Bilimleri Dergisi, 193-202.

Bitirim Okmeydan, S. (2018). Marka Kent Olmaya Giden Yol: İzmir'de Kent Markası Çalışan Illetişim Akademisyenlerine Yönelik Bir Araştirma. The Journal of International Scientific Researches , 111-134.

Deniz, T., \& Yıldııım Kalem, M. (2018). Turizm Coğrafyası: Çalışmalar, Sorunlar ve Yaklaşımlar. Safran Kültür ve Turizm Araştırmaları Dergisi, 41-54.

Doğanay, H., \& Zaman, S. (2016). Türkiye Turizm Coğrafyası. Erzurum: Pegem Akademi Yayınları.

Düzenli, T., Mumcu, S., \& Yılmaz, S. (2019). Kent Kimliğine Simgesel Peyzajın Etkisi. The Turkish Online Journal of Design, Art and Communication - TOJDAC, 438-448.

Emekli, G. (2002). Turizm, Doğu Anadolu ve Ağrı Dağı. Iğdır Valiliği Yayınları. Iğdır.

Everest, A., \& Yılmaz, L. (2019). Mersin Kent Kimliği, Gelenek ve Yenilik : Mersin'de Kent Ekolojisi. Avrasya Sosyal ve Ekonomi Araştirmaları Dergisi (ASEAD), 30-53.

Gezimanya. (2019). Gezimanya. (2019). https://gezimanya.com/strazburg >. Son erişim 13 Ekim. 2019.

Güler, T., Şahnagil, S., \& Güler, H. (2016). Kent Kimliğinin Oluşturulmasında Kültürel Unsurların Önemi : Balıkesir Üzerine Bir İnceleme. Ekonomi, Sosyoloji ve Politika Dergisi, 85-104.

Karadağ, A., \& Mirioğlu, G. (2014). Türkiye'de Kentsel Dönüşüm Politikaları ve Uygulamaları Üzerine Coğrafi Değerlendirmeler : İzmir Örneği. Ege Coğrafya Dergisi, 41-57.

Kavaratzis, M. (2007). City marketing: The past, the present. Geography Compass 1 (3), 695-712.

Kaypak, Ş. (2010). Antakya'nın Kent Kimliği Açısından İrdelenmesi. Mustafa Kemal Üniversitesi Sosyal Bilimler Enstitüsü Dergisi, 373392.

Kervankıran, I.., \& Çuhadar, M. (2014). Turizm Rotalarının Oluşturulmasında Coğrafi Bilgi Sistemlerinin Önemi. Turizm Rotalarının Oluşturulmasında Coğrafi Bilgi Sistemlerinin Önemi. III. Disiplinlerarası Turizm Araştırmaları Kongresi: 576-589. Kuşadası, Aydın

Kılınç, G. (2010). Roma Dönemi Floransa Kenti ve Günümüze Gelen Izleri.Yıldız Teknik Üniversitesi Basılmamış Yüksek Lisans Tezi. İstanbul

Martin, A. (2019). Anholt-GfK CBI pressrelease. GFK: https://www.gfk.com/fileadmin/user_upload/dyna_content/GB/ documents/Press_Releases/2018/20180130_AnholtGfK_CBI_2017_press_release_UK.pdf > Son erişim 2 Ekim 2019.

Özgüç, N. (2015). Turizm Coğrafyası, İstanbul: Çantay Kitabevi.

Özgür, E., \& Yasak, Ü. (2009). Şehir İçi İkametgâh Hareketliliğine Kuramsal Bir Bakış. Coğrafi Bilimler Dergisi, 39-50.

Plaza, B. (2007). The Bilbao effect (Guggenheim Museum Bilbao). Munich Personal RePEc Archive, 1-6.

Polat, S., Aktaş Polat, S., \& Halis, M. (2013). Kent Kimliği Kapsamında Festivallerin Değerlendirilmesi: Uluslararası Altın Safran Film Festivali Örneği. Turizm ve Araştırma Dergisi, 69-85.

Sequeira, T., \& Nunes, P. (2008). Does Tourism Influence Economic Growth? A Dynamic Panel Data Approach. Applied Economics, 129.

Pike, S. (2005). Tourism Destination Branding Complexity . Journal of Product \& Brand Management, 1-4.

Plaza, B. (2007). The Bilbao effect (Guggenheim Museum Bilbao). Munich Personal RePEc Archive, 1-6.

Polat, S., Aktaş Polat, S., \& Halis, M. (2013). Kent Kimliği Kapsamında Festivallerin Değerlendirilmesi: Uluslararası Altın Safran 
Film Festivali Örneği. Turizm ve Araştırma Dergisi, 69-85.

Polat, S., Aktaş Polat, S., \& Halis, M. (2013). Kent Kimliği Kapsamında Festivallerin Değerlendirilmesi: Uluslararası Altın Safran Film Festivali Örneği. Turizm ve Araștırma Dergisi, 69-85.

Sequeira, T., \& Nunes, P. (2008). Does Tourism Influence Economic Growth? A Dynamic Panel Data Approach. Applied Economics, 1-29.

Smith, V., \& Eadington , W. (1992). Tourism Alternatives: Potentials and Problems in the Development of Tourism. University of Pennsylvania Press. Pennsylvania.

Statista. (2020). Statista. Statista Web Sitesi: <www.statista.com > Son erişim 25 Şubat 2020.

Theng, S., Qiong, X., \& Tatar, C. (2015). Mass Tourism vs Alternative Tourism? Challenges and New Positionings. Études caribéennes, 1-7.

Turgut, H., Yavuz Özalp, A., \& Erdoğan, A. (2012). Artvin İlinde Doğal Çevrenin Kent Kimliğine Etkileri. Süleyman Demirel Üniversitesi Orman Fakultesi Dergisi, 172-180.

Yalım, F. (2018). Yavaş Şehir (Cittaslow) Hareketi Ekseninde Kent Markalaşması ve Kent Illetişimi: Kırklareli "Vize" Yavaş Şehir Örneği. Trakya Üniversitesi iktisadi ve Idari Bilimler Fakültesi Dergisi, 128.

Yıldız, Z. (2011). Turizm Sektörünün Gelişimi ve İstihdam Üzerindeki Etkisi. Süleyman Demirel Üniversitesi Vizyoner Dergisi, 54-71.

Young, C., \& Kaczmarek, S. (2008). The Socialist Past and Postsocial Urban Identify in Central and Eastern Europe : The Case of Lodz, Poland. European Urban and Regional Studies, 53-70. 